Journal of Engineering and Applied Sciences 15 (4): 938-947, 2020

ISSN: 1816-949X

(C) Medwell Journals, 2020

\title{
eBiology Interactive Learning for Biology in Secondary School
}

\author{
${ }^{1}$ Faridah Yahya, ${ }^{1}$ Nur Syahirah Zainuddin and ${ }^{2}$ Adidah Lajis \\ ${ }^{1}$ Department of Computer Engineering Section, Universiti Kuala Lumpur, Malaysian Institute of \\ Information Technology, 1016, Jalan Sultan Ismail, 50250 Kuala Lumpur, Malaysia \\ ${ }^{2}$ Centre for Research and Innovation, Universiti Kuala Lumpur, 1016, Jalan Sultan Ismail, \\ 50250 Kuala Lumpur, Malaysia
}

\begin{abstract}
Teaching aids materials are widely used in the process of teaching and learning in the current century in order to stimulate the interest of students. Multimedia tools combined these materials improved student's understanding of the subject. This project aimed at using technology by embedding it in the teaching tools. Prototype of the project built with the concept of interactive teaching aid for teachers to deliver information to student effectively. Biology subject chosen due to the complexity and many facts that need to be memorize. It is a form 4 subject under Malaysian education syllabus for science stream. Selected topic for the subject known as nutrition. Using MIT App inventor, online programming software, the interactive application developed with elements of multimedia and user interfaces. Android operating system used as the building platform. The prototype equipped with questions to test student knowledge. The prototype project successfully built and deployed as an application for android smartphone users. User acceptance test done randomly by selected students in form 4 and 5 of selected secondary school in Malaysia. Questionnaires given to 10 selected respondent to analyses on the usage of the prototype application. Tests done in the web browser and android-base phone. Selected users tested the application successfully.
\end{abstract}

Key words: Teaching aids, multimedia, tools, interactive, prototype, application, android, user interface

\section{INTRODUCTION}

Education is a light that shows the humanity the right direction to surge. The purpose of education is not just making a student literate but adds rationale thinking, knowledgeability and self-sufficiency. 'When there is a willingness to change, there is hope for progress in any field', taken from teaching material of Damodharan and Rengarajan (2007). In the Al-Quran, Surah al-Fathir, verse 35:28 translated that 'And of men and Ad-Dawab (moving living creatures, beasts, etc.) and cattle in like manner of various colours. It is only those who have knowledge among his slaves that fear Allah. Verily, Allah is All-Mighty, Oft-Forgiving'. This verse states the word 'knowledge' and it appears many times in the Quran. The Quran is fill with references to learning, education and observations as written by Syed (2015) and the use of it in daily life. The Quran also motivates people to do scientific research as in verse 39:33, recited 'And who so, brings the truth and believes therein such are the dutiful'.

The process of learning and teaching is tedious and monotonous when one confine to only textbook. It becomes interesting when using many ways to learn from such as storybooks, gadgets, magazine, newspapers, movies, television, radio, travelling and many more (Syed, 2015). Creativity can be develop and innovation benefits both students and teachers. In a research finding (Dolenc and Abersek, 2015), it reported of positive feedback on the integration of e-Learning systems with the traditional classroom teaching. The system strengthen students understanding and knowledge. Another researcher identified (Peck et al., 2015) computer-based system helped students with problems in learning, acting as lifelines to these students.

Choosing the appropriate teaching aids is important in this process. Teaching aids are tools that helps teachers to engage student's interest in classroom. These can be as basics as blackboard or whiteboard. Audio and visual equipment such as DVD player and video projectors are commonly use as tools for learning with a very effective output. Implementing tools in the process of learning can get more participations of the student's as reported by (Parsons and Taylor, 2011). It is also important because they can create a visual and interactive experience for the students. There are many factors for an e-Learning system to be successful (Alhabeeb and Rowley, 2017) such as instructional design and support, students attitude and others.

Interactive learning is another educational approach that integrates social networking and computing into course design and delivery. Interactive learning has changed out the hyper-growth in the consumption of the digital technology and virtual communication, particularly

Corresponding Author: Faridah Yahya, Department of Computer Engineering Section, Universiti Kuala Lumpur, Malaysian Institute of Information Technology, 1016, Jalan Sultan Ismail, 50250 Kuala Lumpur, Malaysia, Contact Number +601132478560 


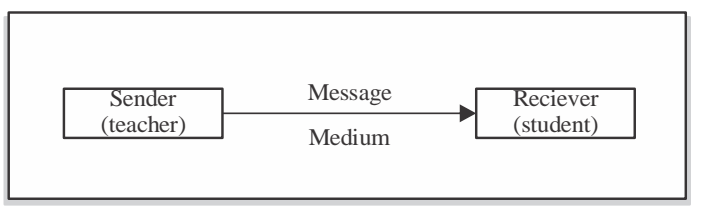

Fig. 1: Chalk and talk method (Damodharan and Rengarajan, 2007)

by students. Another feasibility study by Kennedy et al. (Mwakisole et al., 2018) found that operation of e-Learning system for schools in Tanzania is much needed.

Before technology become essential, in the scope of education (Damodharan and Rengarajan, 2007), teacher is the sender, education materials are the information and student is the receiver of the information. In terms of delivery medium, the teacher can deliver the information via. "chalk-and-talk method" shown in Fig. 1.

The "chalk-and-talk" method is "one way flow" of information (Damodharan and Rengarajan, 2007). In this context, students have passive involvement and teacher is the holder of all factual knowledge and information. In other word, the teacher's delivers to the lecture content and the student listen to the lecture. Teachers perceived as the garden of knowledge while students have minimal or zero previous knowledge in the conventional teaching method.

In the current technology era, the change of roles become important. Teachers are no more the be-holder of all facts and knowledge but they act as companion and mentor to students. Students take the role as an active learner and decide on their own path of learning. Research findings by Miller et al. (2013) concludes that using engaging lecture methods are more effective, less disturbance during lecture and confidence level with the materials are high compared to conventional method.

Both student and teacher work together to get the knowledge and share their information, not just inclusive of instructions but expansion of the knowledge. In the technological world, teacher's roles as keeper of knowledge become facilitator of learning, these presents a challenge and opportunity for them to change the way their student changes. Interactive learning lessen the boundaries between teachers and learners.

This is a final year project of an interactive teaching aid for form 4 Biology subject that make student more focus and bringing excitement in their study. Multimedia element embedded in this application.

Literature review: Currently, education based applications (Doherty et al., 2015; Stotz et al., 2017) are becoming the niche. Previously, known as Computer-Based Training program (CBT) (None, 2014) in 1960's. In the same year, PLATO (Programmed Logic
Table 1: Disadvantages of traditional teaching student vs. teacher

\begin{tabular}{ll}
\hline Student & Teacher \\
\hline Focus is set to the wrong & Deliver within limited time, not \\
path, more on taking notes & enough time for in class exercises \\
Unable to grasp key ideas & Tried to get too much information \\
and concepts & in limited time space \\
Not enough time to & Teacher as the center of information \\
experiment new concepts & \\
\hline
\end{tabular}

for Automated Teaching Operations Research) was introduced (None, 2014), built for University of Illinois students.

Now with the involvement of internet and easily available materials, making this area of research more interesting. In current researches, they (Popovici and Mironov, 2015) reported that to implement e-Learning in higher education, a well-planned and systematic approach is vital. Recently, many other terms also come up to describe the same method of learning such as "online learning”, "virtual learning”, "e-Learning” and many others to come.

Researchers in "Kids Online multimedia courseware of Math and Animal" (Ching, 2013) concentrated on mathematics and animal for kids aged $4-5$ years old. Kids can choose to learn the course as they like. It contains two subjects for fun learning which is mathematical and animal. They can practice through the flash game. It does not include complicated features in user interface. Kids can learn through the system and play the education game. The courseware is free access for all individual and has greatly improve in user interface using Human Computer (HCI) principals. The development of the courseware is using ADDIE Model (Culatta, 2019; Clark, 2019).

Another work by Ginon et al. (2016) used the Open Learner Model (OLM), known to have supporting learning, metacognition, facilitating self-monitoring and planning, improving self-assessment skills, among others. The researchers used the OLM to help teachers to monitor speed-reading. In a research focused on ADHD (Attention Deficit/Hyperactivity Disorder) learner's (Kusumasari et al., 2018), they make use of user interface model of interactive learning application for social science subjects. Children-centered design method implemented and application usability level measured analyzed.

Disadvantages of traditional teaching: In the pre-technology education, mostly school in this country use "teacher-centered" method to deliver the information to the receiver. Traditional teaching has some disadvantage to the teacher or the student as shown in Table 1.

Traditional teaching aids: The common traditional teaching aids, Fig. 2 are blackboards, whiteboard, textbooks, charts and pictures. Blackboard is one of the 
(a)

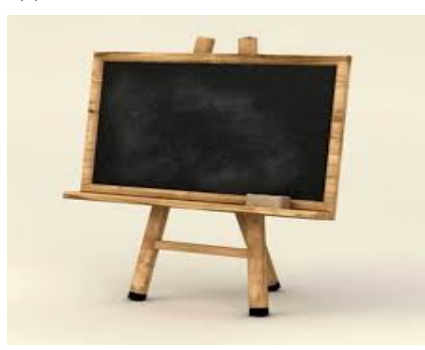

(c) (b)

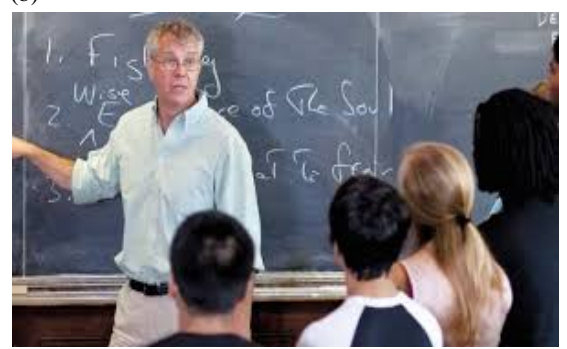

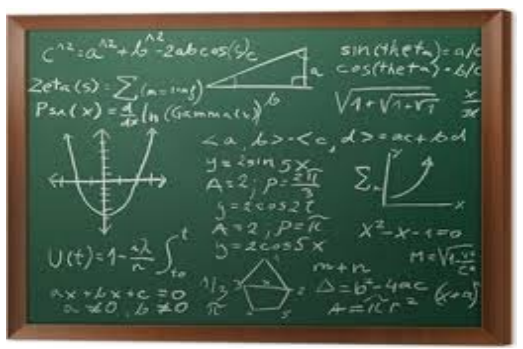

Fig. 2(a-c): Traditional teaching aids

oldest and the most used teaching aids either in schools of universities. The teacher has to take white chalk to describe the things on the blackboard for the student to copy it while some teachers used colourful chalk to emphasize upon the important lessons. Textbooks also the most useful teaching aids in order to teach a lesson. Most of the school provide the textbook to their student and teacher referred to the textbook before they delivered a lesson to the student. Textbooks provide information and pictures for better understanding.

Interactive learning: Course design and delivery incorporated interactive learning, a pedagogical approach that uses social networking and urban computing. Interactive learning has evolved out the hyper-growth in the use of the digital technology and virtual communication, particularly by students.

According to Stanford University School of Medicine (SUSM., 2019), lesson can be change into discussions and student along with the teachers become partner in the journey of the knowledge acquisition. Non-attending student also can strengthen their critical thinking and problem solving skills using a much more holistic approach to learn. Famous TEFL author and education industry voicer, Scrivener (2019), stated that teacher's role is to "help the learning to happen". This includes involving the student in what is going on by enabling them to work on their own by not giving too long presentation and encourage them to actively participate in classes activities such as talk and interact with other people. "The teacher vary along a continuum of beliefs about their student to learn to behave and conceptualized this as one's pupil-control ideology" (Willower, 1975) adapted.

Multimedia as education tool: Combination of more than or inclusive of two different information media within a computer system famously known as multimedia. Media can be included text, audio, video and animation. Researchers (Vaughan, 2014) also stated that multimedia is a combination of digitally text, audio, picture and animation.

Multimedia does not have to be too interactive. For example, the lesson may involve the student to click on a symbol represent next action. According to Fenrich (2005), multimedia is the exciting combination of hardware that allows you to integrate video, animation and audio to develop effective presentation on affordable desktop computer.

Multimedia being powerful tool for making interactive teaching, it also offer unique advantages in the teaching field. For example in Biology subject an instructor cannot make a killer whale come alive in classroom. Multimedia enable make the student experience their subject in a vicarious manner. Use of multimedia as education tools shown by the popularity of the many games application available in the Google Play Store and Mac App Store.

MIT App inventor and proshow producer: This inventor is an open-source web application for Android 
(a)

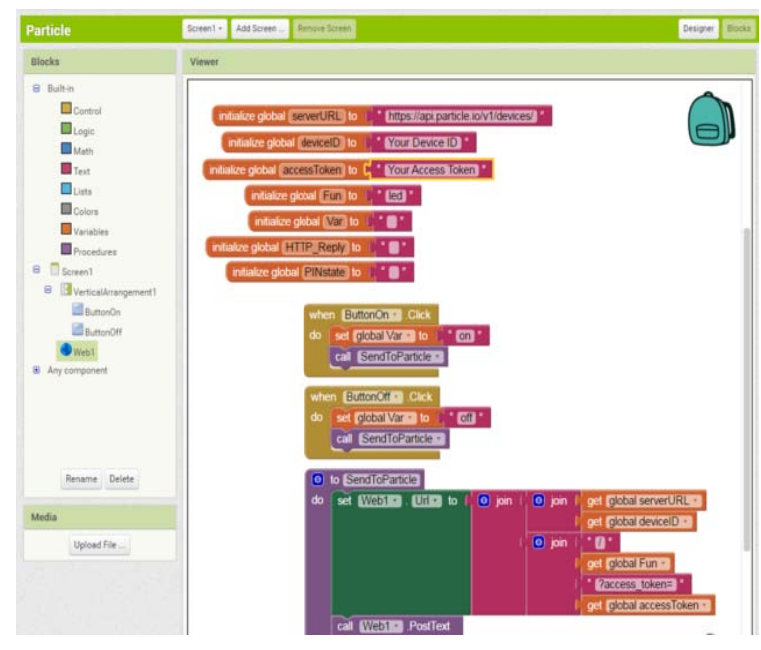

(b)

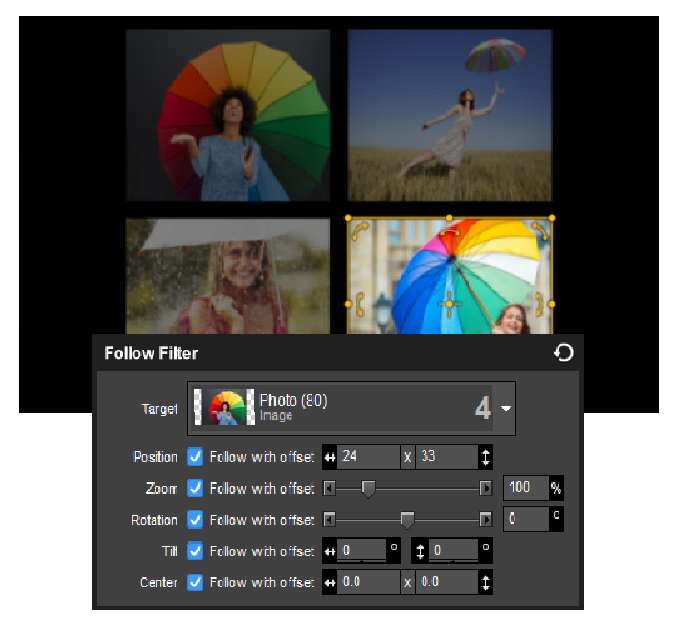

Fig. 3(a, b): MIT App Inventor and Proshow Producer Softwares (Albittron, 2019)

and initially owned by Google in 2010 but now maintained by the Massachusetts Institute of Technology. It used an easy drag and drop method coding or by dragging visual objects to App development. It make use of Java, Kawa and Scheme programming language. Both softwares shown in Fig. 3.

Proshow Producer Software in Fig. 3, used for animation purpose in this courseware interactive project. It makes good combination of animation with the App inventor.

Effectiveness of multimedia on student's performance: Multimedia provides easiness for student to understand more in their lesson. Researchers stated that student could gain the information that would be impossible to find in traditional education, beside they could find the opportunity to prepare their own product with multimedia. Multimedia possesses the objective of helping the student with different skills and learning styles. Another group of researchers found that multimedia reaches the student in various ways and thus, it provides a richer learning environment. The subject conveyed to student using web-based audio, visual and video in a way that cannot be taught in classroom. Researchers also reported that it increased the academic achievement of student. They also concluded, "the use of multimedia affects education positively when designed properly compared to traditional teaching in terms of academic achievement”.

In a recent research on the effectiveness of multimedia approach on the academic achievement (Kaur et al., 2015) concluded that the findings supported the effectiveness of multimedia in student performance.
Table 2: Comparison of Agile, ADDIE and Waterfall models Type of model

\begin{tabular}{|c|c|c|}
\hline Agile & ADDIE & Waterfall \\
\hline \multicolumn{3}{|l|}{$\overline{\text { Design }}$} \\
\hline Planning & Analysis & Requirement analysis \\
\hline Requirement analysis & Design & System design \\
\hline Design & Development & Implementation \\
\hline Building & Implementation & Testing \\
\hline Testing & Evaluation & $\begin{array}{l}\text { Deployment } \\
\text { Maintenance }\end{array}$ \\
\hline \multicolumn{3}{|l|}{ Advantage } \\
\hline $\begin{array}{l}\text { Easy to manage } \\
\text { Little planning required } \\
\text { Functionality can } \\
\text { developed rapidly }\end{array}$ & $\begin{array}{l}\text { Provide step by } \\
\text { step process } \\
\text { Leads to better } \\
\text { result from } \\
\text { learner's point }\end{array}$ & $\begin{array}{l}\text { Simple and easy } \\
\text { Phased are processed } \\
\text { and complete at one } \\
\text { time } \\
\text { Clearly defined stages }\end{array}$ \\
\hline \multicolumn{3}{|l|}{ Drawback } \\
\hline $\begin{array}{l}\text { Not suitable for handling } \\
\text { complex dependencies } \\
\text { More risk of sustainability }\end{array}$ & $\begin{array}{l}\text { Not iterative } \\
\text { Very time } \\
\text { consuming model }\end{array}$ & $\begin{array}{l}\text { Poor mode for long and } \\
\text { ongoing process } \\
\text { Not good for complex } \\
\text { projects } \\
\text { High risk amount }\end{array}$ \\
\hline
\end{tabular}

\section{MATERIALS AND METHODS}

Methods used: This project considered three types of software development life cycle. Agile Model chosen for the development of this prototype. Table 2 showed the comparison of the software development model.

Agile Model: Every aspect of development is continually revisited throughout the lifecycle of the project in this model. It only required little planning and easy to manage for not complex project. The prototype system more suitable with the Agile Model Software development. Agile model is a combination of iterative and incremental process models, Fig. 4, focusing on process, customer satisfaction by rapid delivery of working software product. 
User requirements: Figure 5 shows the use case diagram implemented in this mobile application prototype development. Use case diagram is a required information gathered from the user.

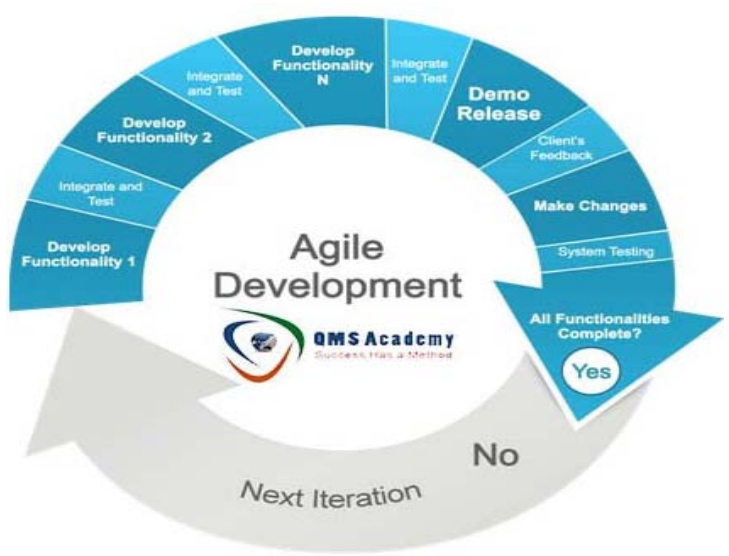

Fig. 4: Agile SDLC Model (QMS Academy, 2019)
Design and implementation: For the purpose of design, flowchart, depicted in Fig. 6, used to show the flow of the prototype. Figure 7-10 are the screen

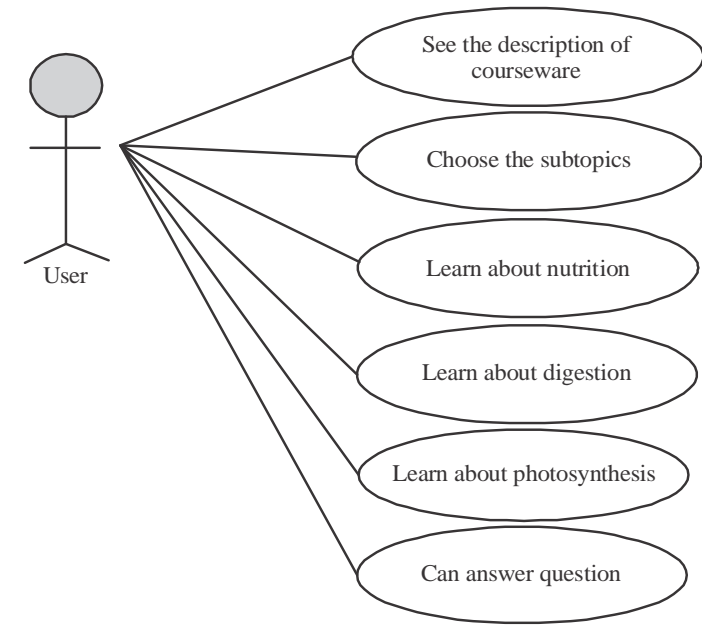

Fig. 5: Use case diagram prototype

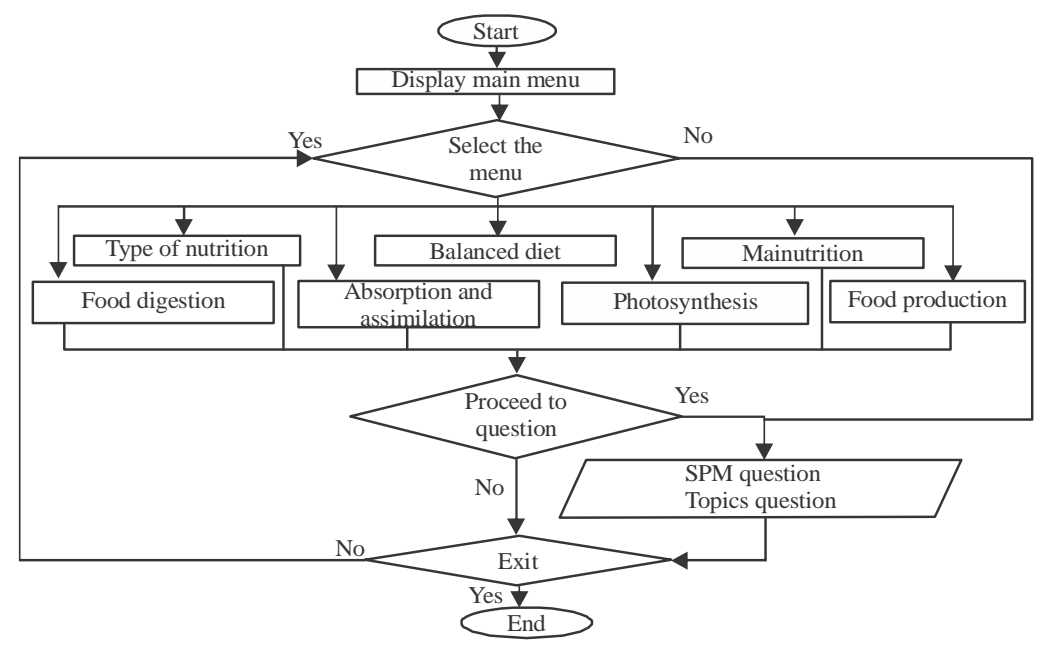

Fig. 6: Flowchart of prototype

(a)
\begin{tabular}{|c|l|}
\hline Label & \multicolumn{1}{|c|}{ Description } \\
\hline L1 & Title of courseware \\
\hline B1 & "Type of nutrition" \\
\hline B2 & "Balanced diet" \\
\hline B3 & "Malnutrion" \\
\hline B4 & "Food digestion" \\
\hline B5 & "Absorption and assimilation" \\
\hline B6 & "Formation of faces and defacation" \\
\hline B7 & "Evaluation eating habits" \\
\hline B8 & "Importance of healthy digestion" \\
\hline B9 & $\begin{array}{l}\text { "Importance of macronutrients and } \\
\text { micronutrients in plant" }\end{array}$ \\
\hline B10 & "Photosynthesis" \\
\hline B11 & "The mechanism of photosynthesis" \\
\hline B12 & "The factor of affecting photosynthesis" \\
\hline B13 & "A caring attitude towards plants" \\
\hline B14 & "Technology used in food production" \\
\hline B15 & $\begin{array}{l}\text { "Technological development in } \\
\text { food production" }\end{array}$ \\
\hline B16 & "Question" \\
\hline
\end{tabular}

\begin{tabular}{|c|c|}
\hline \multicolumn{2}{|c|}{ L1 } \\
\hline B1 & B2 \\
\hline B3 & B4 \\
\hline B5 & B6 \\
\hline B7 & B8 \\
\hline B9 & B10 \\
\hline B11 & B12 \\
\hline B13 & B14 \\
\hline B15 & B16 \\
\hline
\end{tabular}

Fig. 7(a, b): Storyboarding 
(a)

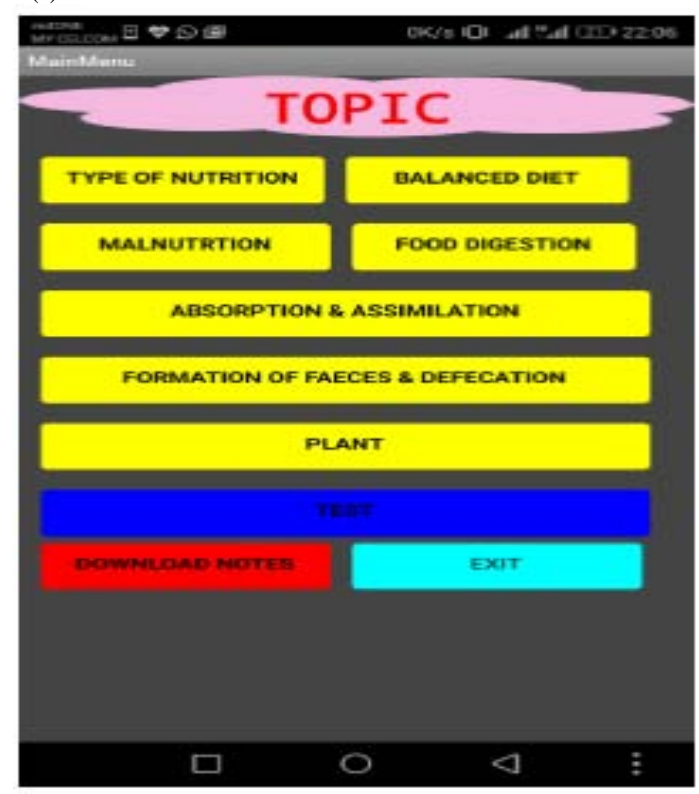

(b)
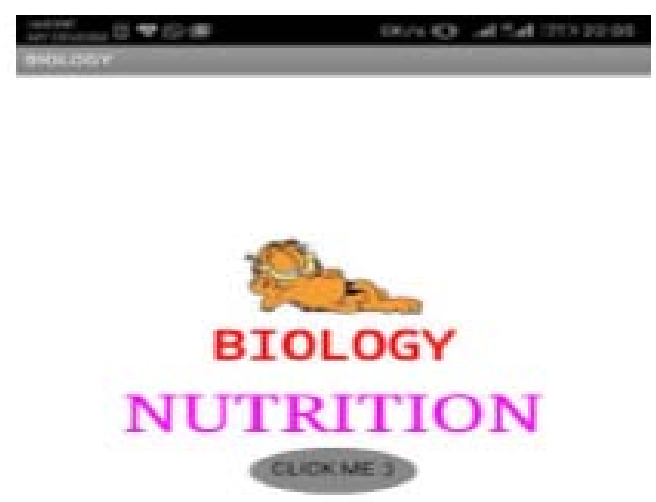

무

C

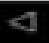

Fig. 8(a, b): Screen shot of initial page

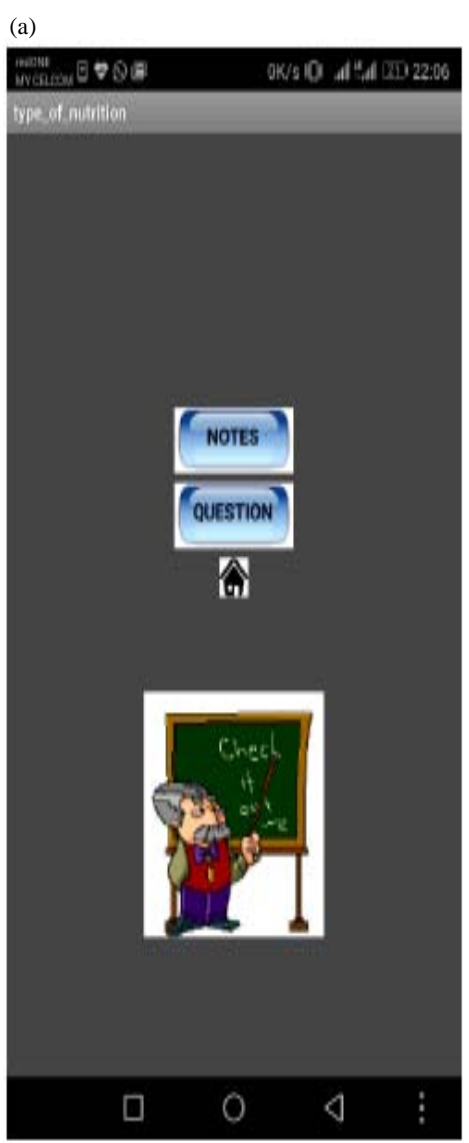

(b)

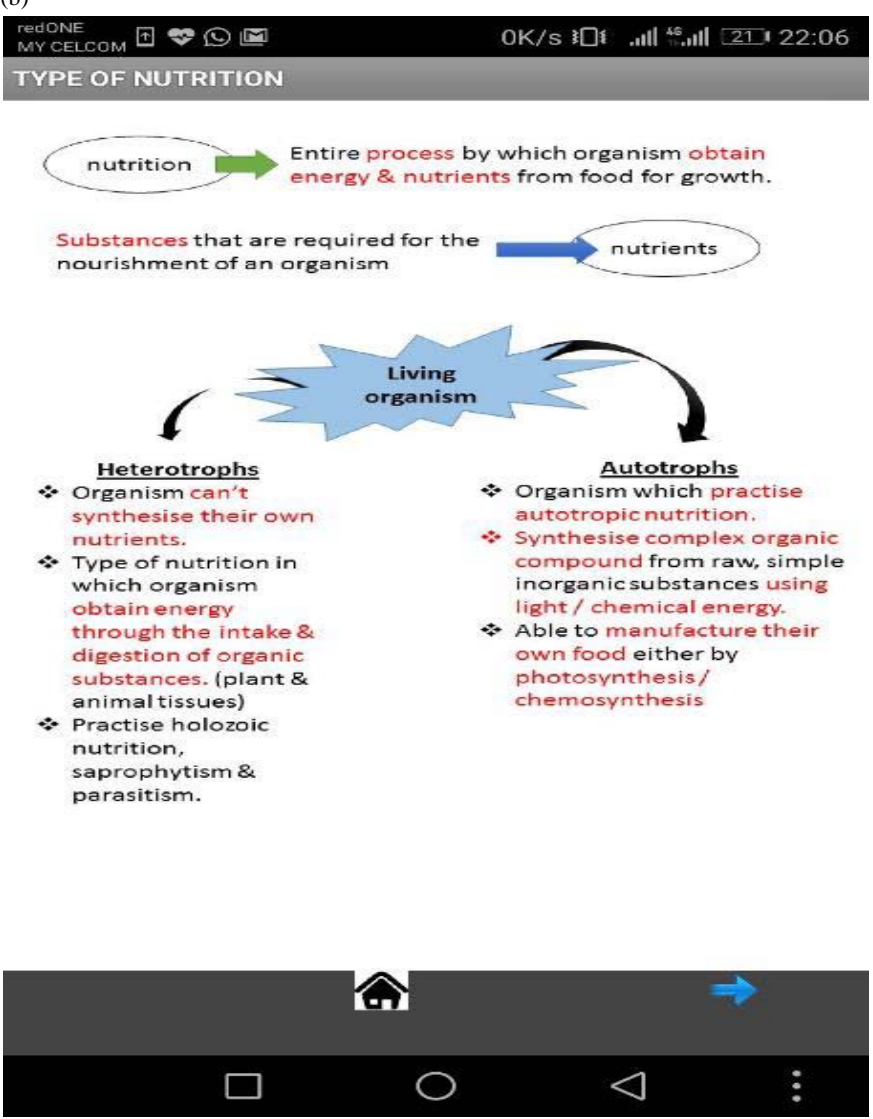

Fig. 9(a, b): Screen shot of process 
(a)

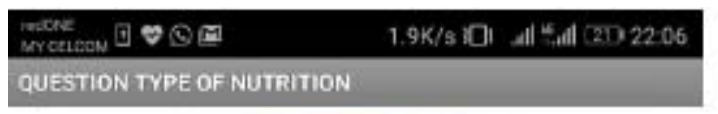

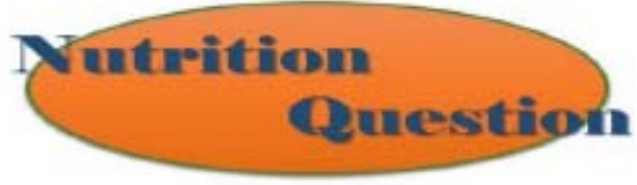

1. Entire process by which organism obtain energy \& nutrients from food for growth.

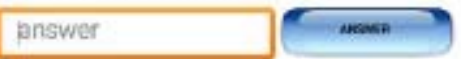

2. Autotrophs \&__ are the living orgarism that can be divide into 2 main group based on their nutritional

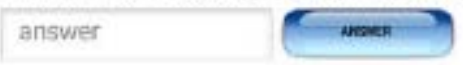

3. Substances that are required for nourishment of an organism.

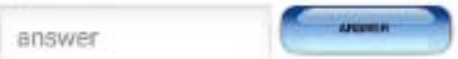

4. An organism that synthesises its own organic compound from simple inorganic substances is known as

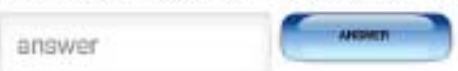

5. obtain mutrients by living on / in the body of another living thing organism, host.

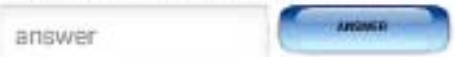

SCORE: 0 out of 5 .

$\square$

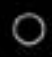

(b)

\begin{tabular}{|c|c|}
\hline 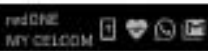 & 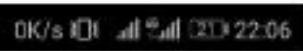 \\
\hline TEST EIDLOEY & \\
\hline
\end{tabular}
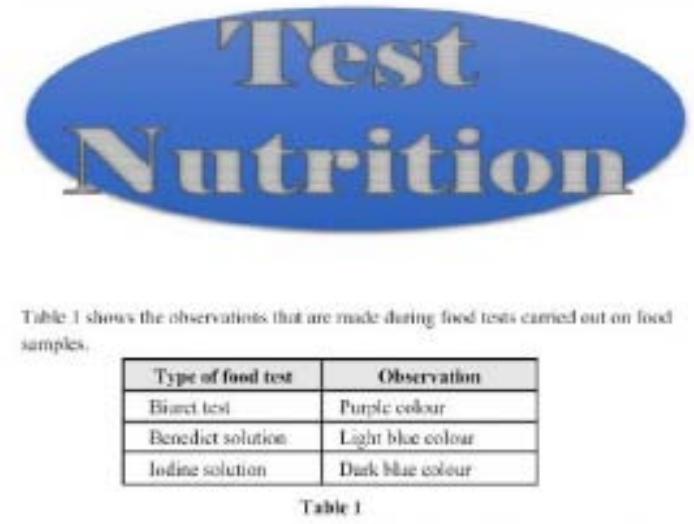

Bused on the resals above, which of the following conckisian about the fond samples is cartect?

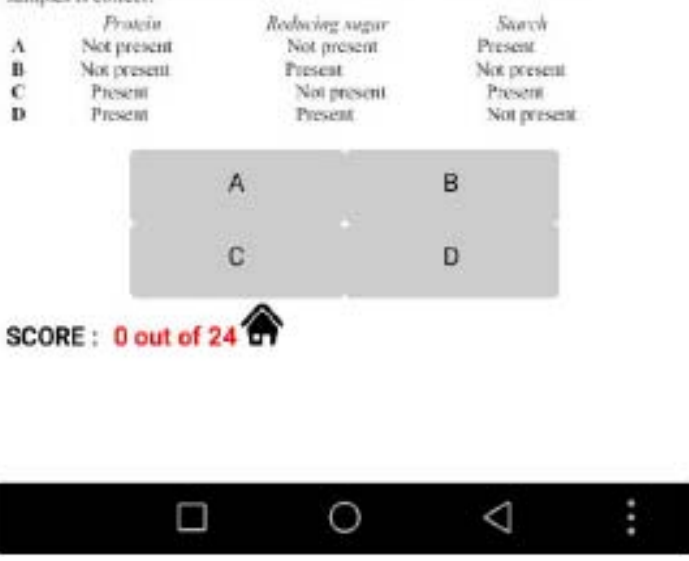

Fig. 10(a, b): Screen shot questions

shots of the prototype system. Each figures has different function as shown in the story boarding of Fig. 7.

\section{RESULTS AND DISCUSSION}

Testing and results: This is the crucial part in developing the prototype. It is crucial as a defect in software can bring damage to human being, the environment or to the team. Due to time constraints, creator chose to concentrate on three levels of software testing. They consists of: integration, system and unit testing. Unit testing is a type of functional test to test if there are any errors/bugs on every single page created by creator. It is done incrementally for all unit as it will become a problem if testing done only after the whole system has been created. After the developer writes coding, pages are tested to perform the functionality.

To test integration between pages in MIT App inventor, the developer uses integration testing-Ad-hoc. It is intended to test parameter passing between pages either it is successful and able to interact between pages and links. It can also test the integration between the apps and device.

To test the functionality of the whole system and to see either the functionality of system are working or not, system testing is done to perform the task. Another types of testing employed by the creator of this app is User Acceptance Test (UAT), another type of functional test and questionnaires. Both methods discussed further in next section.

User Acceptance Test (UAT) and questionnaire: Figure 11 is the sample of acceptance test done for this prototype. UAT focused on the view and opinion of the client/user.

Selected users from the secondary/high school of MRSM Felda Trolak, SMK King George V and teachers from SMK Bandar Enstek, Malaysia performed the test. 


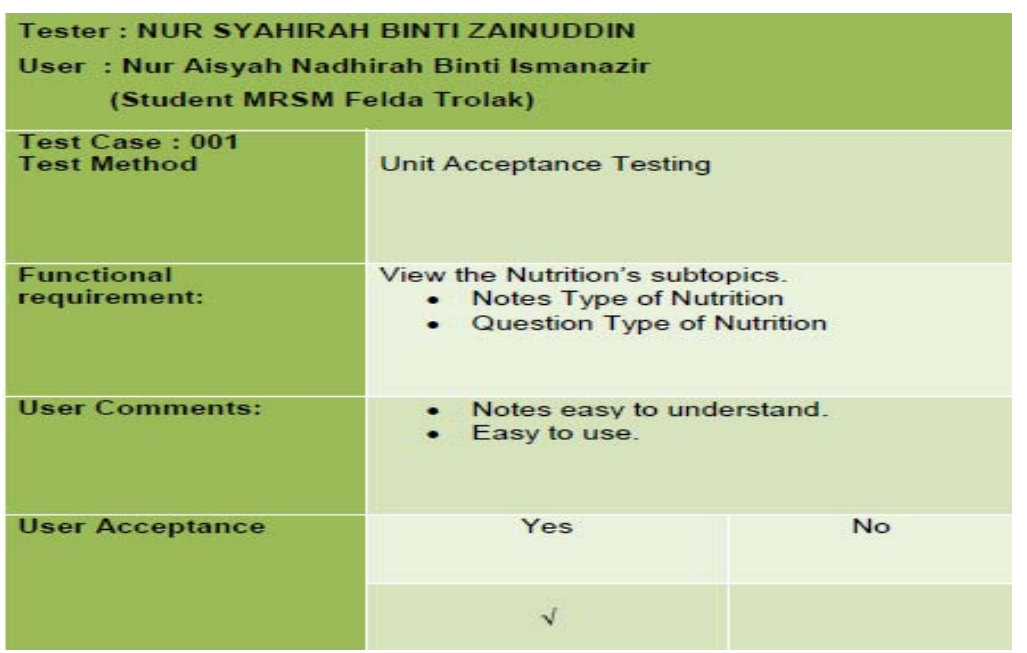

Fig. 11: User acceptance

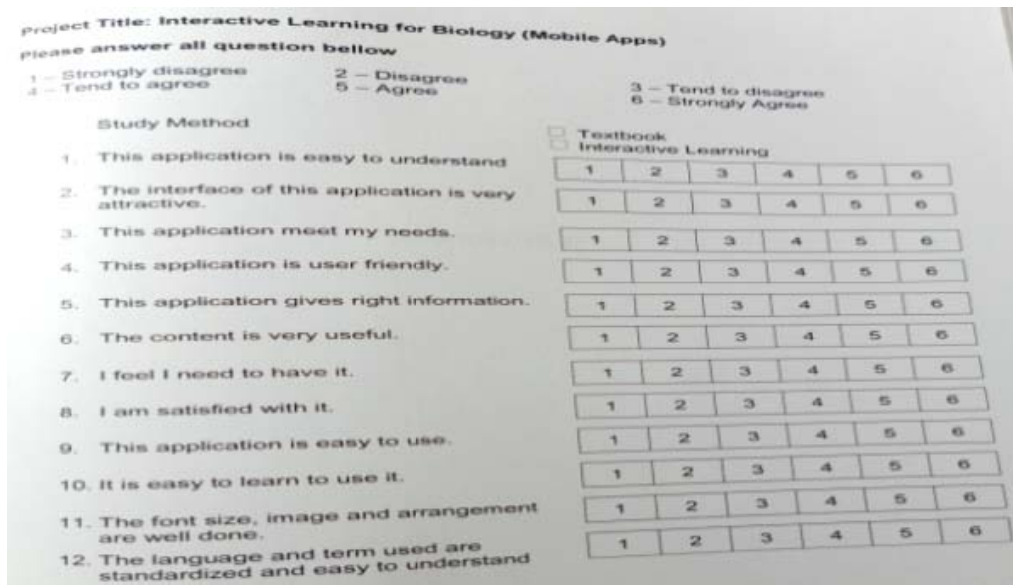

Fig. 12: The 12 questions

The results showed positive feedback as most of the users stated that the prototype easy to understand and used.

Questionnaires were also given to ten respondents consists of teacher and students of high schools from Negeri Sembilan, Malaysia. They are required to answer only twelve questions in Fig. 12 with scale ratings of 1-strongly disagree to 6-strong agree. In conclusion, the survey presented that $80 \%$ respondents strongly agreed that the Apps is user friendly while $50 \%$ tend to agree that the overall design of the App is interactive.

\section{CONCLUSION}

Employing technology either the internet or the software applications in teaching and learning is crucial for new generations. Interactive applications with multimedia will not replace the role of educator. These applications software complemented the journey in education. This study described the development of mobile application "eBiology Interactive Learning" using open source software. Costs of developing the application is low. Results of testing done proved that the mobile prototype system function as required.

The system targeted for secondary school student in Malaysia and developed as the mobile application to supplement the subject. Based on the findings from the 10 questionnaires, majority of them agreed that the application is useful as one of their learning aids. Teachers also found that this application is also suitable as their teaching aids.

Selected important features can be added to this mobile application prototype or for other development using different mobile operating system. Overall, this prototype application function as expected and can provide as a base for others to develop the same application. 


\section{SIGNIFICANCE STATEMENT}

Two important aspects are mentioned in this study: e-Learning has to integrate current technology in information, computer sciences and engineering for uses in education to attract new era of million students. Without the use of current and expanding of technologies in communication, delivering of educations maybe halted and mild. In the end, education can only reached minute of the world population and becoming a waste.

Re-engineering of the education and information technology industries, requires education to also change accordingly while preserving the current methods in teaching. The traditional method of "teacher-chalk-talk" is still needed in conveying intended important messages but combinations with other technology is a bonus towards young and old generations.

\section{ACKNOWLEDGEMENT}

Researchers would like to thank all personnel involved in writing and reviewing this study, so that, it will of gain to others in near future. Our gratitude are extended to Universiti Kuala Lumpur, Malaysia, Computer Engineering Section MIIT, Centre of Research, Bachelor of Computer Engineering student (Nur Syahirah Zainuddin) and Dr Adidah Lajis, CCIT 2019 last but not least Medwell Publications (JEAS).

\section{REFERENCES}

Albittron, R., 2019. What is app inventor: MIT app inventor. Adafruit Industries Company, New York, USA. https://learn.adafruit.com/mit-app-inventorand-particle-io/what-is-app-inventor

Alhabeeb, A. and J. Rowley, 2017. Critical success factors for eLearning in Saudi Arabian universities. Int. J. Educ. Manage., 31: 131-147.

Ching, L.W., 2013. Kids online multimedia courseware of Math and animal. B.Sc. Thesis, Tunku Abdul Rahman University College, Kuala Lumpur, Malaysia.

Clark, D., 2019. Big dog and little dog's performance juxtaposition. American Psychological Association, Washington DC., USA. http://www.nwlink.com / donclark/history_isd/addie.html

Culatta, R., 2019. Instructional design models: ADDIE model. Yellow Rubber Ball, Durham, North Carolina. https://www.instructionaldesign. org/models/addie/

Damodharan, V.S. and V. Rengarajan, 2007. Innovative methods of teaching. Proceedings of the Middle East Conference on Learning Technologies and Mathematics, March 31-April 2, 2007, Sultan Qaboos University, Muscat, Oman, pp: 1-16.
Doherty, I., N. Sharma and D. Harbutt, 2015. Contemporary and future eLearning trends in medical education. Med. Teach., Vol. 37, No. 1. 10.3109/0142159X.2014.947925

Dolenc, K. and B. Abersek, 2015. TECH8 intelligent and adaptive E-learning system: Integration into technology and science classrooms in lower secondary schools. Comput. Educ., 82: 354-365.

Fenrich, P., 2005. What can you do to virtually teach hands-on skills?. Issues Inf. Sci. Inf. Technol., 2: 347-354.

Ginon, B., M. Johnson, A. Turker and M.D. KickmeierRust, 2016. An open learner model used by teachers to monitor speed reading learners. Proceedings of the EC-TEL 2016 International Workshop on Teaching Analytics (IWTA’16), September 16, 2016, Lyon, France, pp: 23-29.

Kaur, R., K. Sharma and S. Singh, 2015. Effectiveness of multimedia approach on the academic achievement of class 8th students in English. Int. J. Applied Res., 1: 467-471.

Kusumasari, D., D. Junaedi and E.R. Kaburuan, 2018. Designing an interactive learning application for ADHD children. Proceedings of the 3rd Annual International Conference on Applied Science and Engineering (AASEC'18) Vol. 197, September 12, 2018, Bandung, Indonesia, pp: 1-5.

Miller, C.J., J. McNear and M.J. Metz, 2013. A comparison of traditional and engaging lecture methods in a large, professional-level course. Adv. Physiol. Educ., 37: 347-355.

Mwakisole, K., M. Kissaka and J. Mtebe, 2018. Feasibility of cloud computing implementation for eLearning in secondary schools in Tanzania. Int. J. Educ. Dev. Using ICT., Vol. 14, No. 1.

None, 2014. Explore talent lms. Epignosis LLC., San Francisco, California, USA.

Parsons, J. and L. Taylor, 2011. Improving student engagement. Curr. Issues Educ., Vol. 14, No. 1.

Peck, C., K.K. Hewitt, C.A. Mullen, C.A. Lashley, J.A. Eldridge and T.R.M.O. Douglas, 2015. Digital youth in brick and mortar schools: Examining the complex interplay of students, technology, education, and change. Teachers Coll. Rec., Vol. 117, No. 5.

Popovici, A. and C. Mironov, 2015. Students perception on using eLearning technologies. Procedia Soc. Behav. Sci., 180: 1514-1519.

QMS Academy, 2019. QMS Academy: Agile development model. QMS Academy Lower Parel, Mumbai, India. https://medium.com/@ amankrs456/qms-academy-agile-developmentmodel-70752fba6a4a

SUSM., 2019. Stanford medicine interactive learning initiatives. Stanford University School of Medicine, California, USA. http://med.stanford.edu/edtech/ portfolio/smili.html 
Scrivener, J., 2019. An interview with Jim Scrivener, TEFL author and industry voice. Frameworks Education Group, Cambridge, UK. https://www. studycelta.com/blog/interviews-with-theauthors/interview-jim-scrivener/

Stotz, S., J.S. Lee, H. Rong and D. Murray, 2017. The feasibility of an eLearning nutrition education program for low-income individuals. Health Promotion Pract., 18: 150-157.
Syed, I.B., 2015. The pleasures of seeking knowledge. IslamiCity.com, Washington DC., USA. https://www.islamicity.org/6580/the-pleasures-ofseeking-knowledge/

Vaughan, T., 2014. Multimedia: Making it Work. 9th Edn., McGraw-Hill Education, New York, USA., ISBN: 9780071832885, Pages: 504.

Willower, D.J., 1975. Theory in educational administration. J. Educ. Administration, 13: 77-91. 